\title{
User Satisfaction of Indoor Environmental Quality in Student Dormitories
}

\author{
Gulsah Yavuz Kocaman ${ }^{1}$, Filiz Senkal Sezer ${ }^{2 *}$, Tuğba Cetinkol ${ }^{3}$
}

\begin{abstract}
:
Dormitories are buildings that continuously provide accommodation to students. Many university students in Turkey prefer to stay in private or state dormitories. The purpose of this study is to understand the criteria that are seen important by students, who stay in dormitories, and to assist the fulfilment of necessary performance specifications of buildings. Another goal is to assist the development of design criteria for new buildings by collecting user opinions related to issues that create dissatisfaction. A hypothesis was developed believing that improvement of structural comfort conditions in dormitories would increase the efficiency of students. In the scope of this study a questionnaire was prepared and used to understand user satisfaction levels related to comfort in three state dormitories located in Uludag University Gorukle Campus in the city of Bursa, which is the 4th largest city in Turkey. The results of the survey were analysed under the following headings: Transportability, Accessibility, Ergonomics in the context of Design and Planning; Thermal Comfort, Audio Comfort, Visual Comfort, and Indoor Air Quality in the context Physical Environmental Control; and Service Areas in the context of Social Environment.
\end{abstract}

Keywords: Structural Comfort, Comfort Conditions, Dormitories

\section{Introduction}

Quality of life is defined as a person's perception on his/her life and used synonymously with the concepts such as satisfaction and pleasure from life, well-being, living conditions, and happiness (Cella, 1996). According to World Health Organization, quality of life is composed of physical conditions, psychological status, social relations inside and outside the family, interaction with the environment and beliefs. Satisfaction from life is one of the most important determinants of general wellbeing and quality of life, and includes elements of a person's subjective perception of the quality of life and wellbeing (Sahin, 2001). Satisfaction from life generally involves a person's whole life and various dimensions of life; it is influenced by age, gender, health, work, economic status, education, religion, marriage, social support and environmental conditions (Matheny, 2002). Satisfaction from life is important for all age groups including university students. Most of the university students in Turkey are educated in a city different than their original home, where they used to live with their parents. In general, the first and one of the most important problems of students in their university education is related to accommodation (Ersoy, 2008). 
Accommodation is one of the most important necessities for providing and sustaining the feeling of security. In Turkey, dormitory buildings in universities are generally separated for males and females. These buildings must be carefully evaluated from necessities, spatial organization and comfort condition perspectives. When these buildings cannot fulfil the necessities, they tend to become sleeping quarters rather than dormitories.

The inability to fully satisfy individual and social needs of students reduces students' satisfaction levels and their quality of life. It also reduces students' motivation for success. It also results in students abandoning their dormitories in time or in the reduction of the number of students that prefer to inhabit such places in the first place. Institutions of higher education are places where knowledge is generated and shared. The ability to carry out high quality research and provision of a comprehensive education does not only rely on the academic environment but also the environment created by the physical and social surroundings. When it is evaluated from such a viewpoint it can be seen that the environment created by the accommodation facilities of higher education institutions that enable necessary comfort conditions for studying and for social interaction will support the creation of a higher quality education environment.

According to the above mentioned ideas, the literature was examined and based on the results, a study to understand user satisfaction on structural comfort conditions was carried out in the state dormitories located at Gorukle Campus of Bursa Uludag University.

The research method is composed of the following stages:

- A research on literature related to the subject area to be analysed, and review of relevant information and knowledge related to indoor requirements,

- Defining issues that users feel dissatisfied and/or complain,

- Preparing a survey to receive feedback from user experience in the designed environment,

- $\quad$ Evaluating the results of the survey to compare them with the defined spatial performance requirements in order to understand the level of satisfaction of users.

In accordance with the information received and when examining literature (Hassanain, 2007), various performance indicators (spatial performance requirements), which were important for the students in the scope of the study, were defined that could enable the fulfilment of the required performance conditions. Evaluation criteria (defined spatial performance requirements) were;

- Design - Planning: Transportability, Accessibility, Ergonomics,

- Physical Environmental Control: Thermal Comfort, Audio Comfort, Visual Comfort, and Indoor Air Quality

- Social Environment: Service Areas.

The purpose of the information gathered from this study and its findings was to evaluate user satisfaction levels, and the suitability of the operational and structural models of student dormitories from the viewpoint of physical environmental control criteria. The information gathered will become a guide for new designs. Also in the scope of this 
research the correctness of the hypothesis: "increasing the comfort standards in dormitories built with the support of the state will increase the motivation of students towards success" will be examined. This study will be important for:

- $\quad$ seeing how the presented comfort conditions are perceived by the students,

- understanding which improvements can be made on problems mentioned by students,

- understanding the priorities of students to create innovative and creative ideas for new dormitories to be built for students.

\section{Case Study}

The area selected for the field study is the Uludag University Gorukle Campus located in Bursa, which is the $4^{\text {th }}$ largest city in Turkey. It is 18 kilometres from the city centre and located on a 16000 decade land. Faculty of Medicine, Faculty of Economics and Administrative Sciences, Faculty of Engineering and Architecture, Veterinary School, Faculty of Agriculture, Faculty of Education, Faculty of Science and Letters, State Conservatory, Health College, Vocational School of Health Care Delivery, Vocational School of Technical Sciences, Prof. Dr. Mete Cengiz Culture Centre, Student Culture Centre, Central Library, Administrative Centres of Institutes, Departments and Rectors Office and the locations selected for this study, which are Guler Osman Koseoglu, Nilufer Hatun, and Rabia Riza Bicen Dormitories, which are operated by Uludag University Health, Culture and Sports Directorate are located in the Gorukle Campus. It is possible to reach the campus via various mass transportation vehicles such as the metro, city bus and private minibuses.
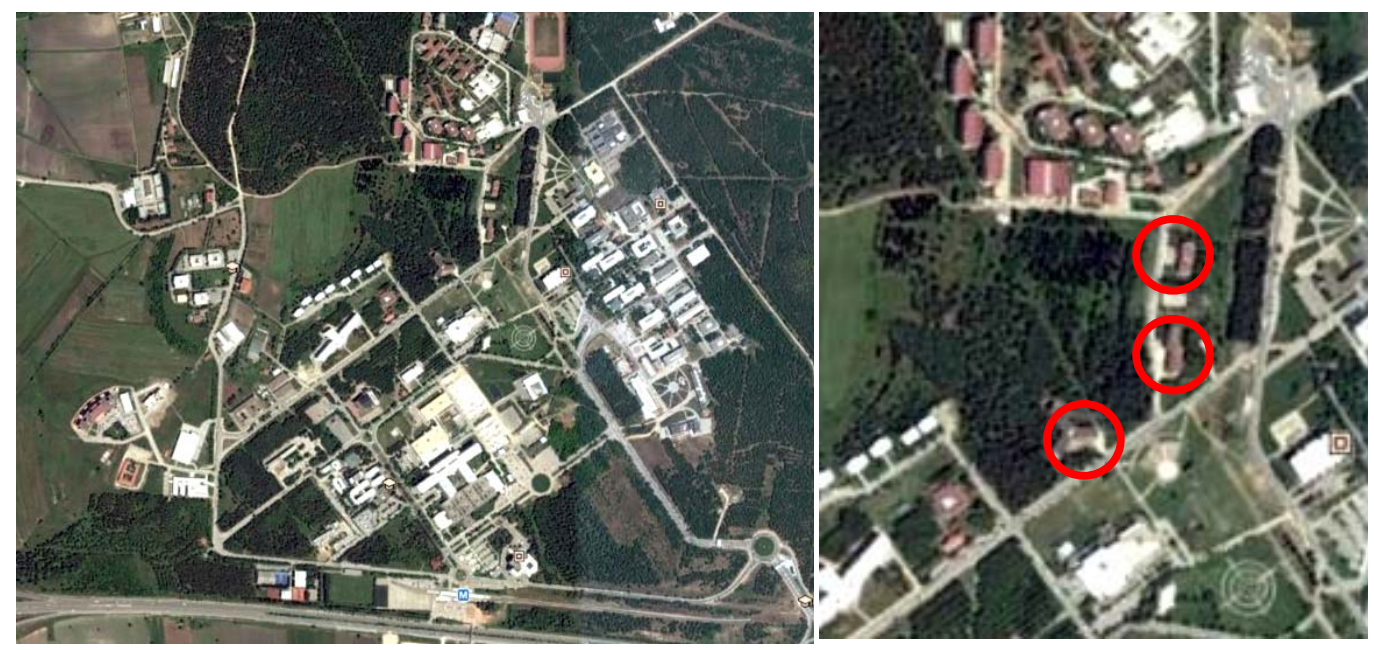

Figure 1. Uludag University Gorukle Campus (Google Earth,2016) 


\section{Definition of the study areas:}

There are 3 dormitories which 540 person capacity on the Görükle Campus. Guler Osman Koseoglu Female Dormitory is a four story building. The building has a study hall, library and TV room, computer hall, laundry washing rooms, laundry drying rooms and baggage rooms. There are no cafeterias but there are vending machines for water, coffee, etc., and various convenience foods. The rooms accommodate 4 people and have kitchens and bathrooms. There is an elevator, a main staircase and a fire escape in the building.
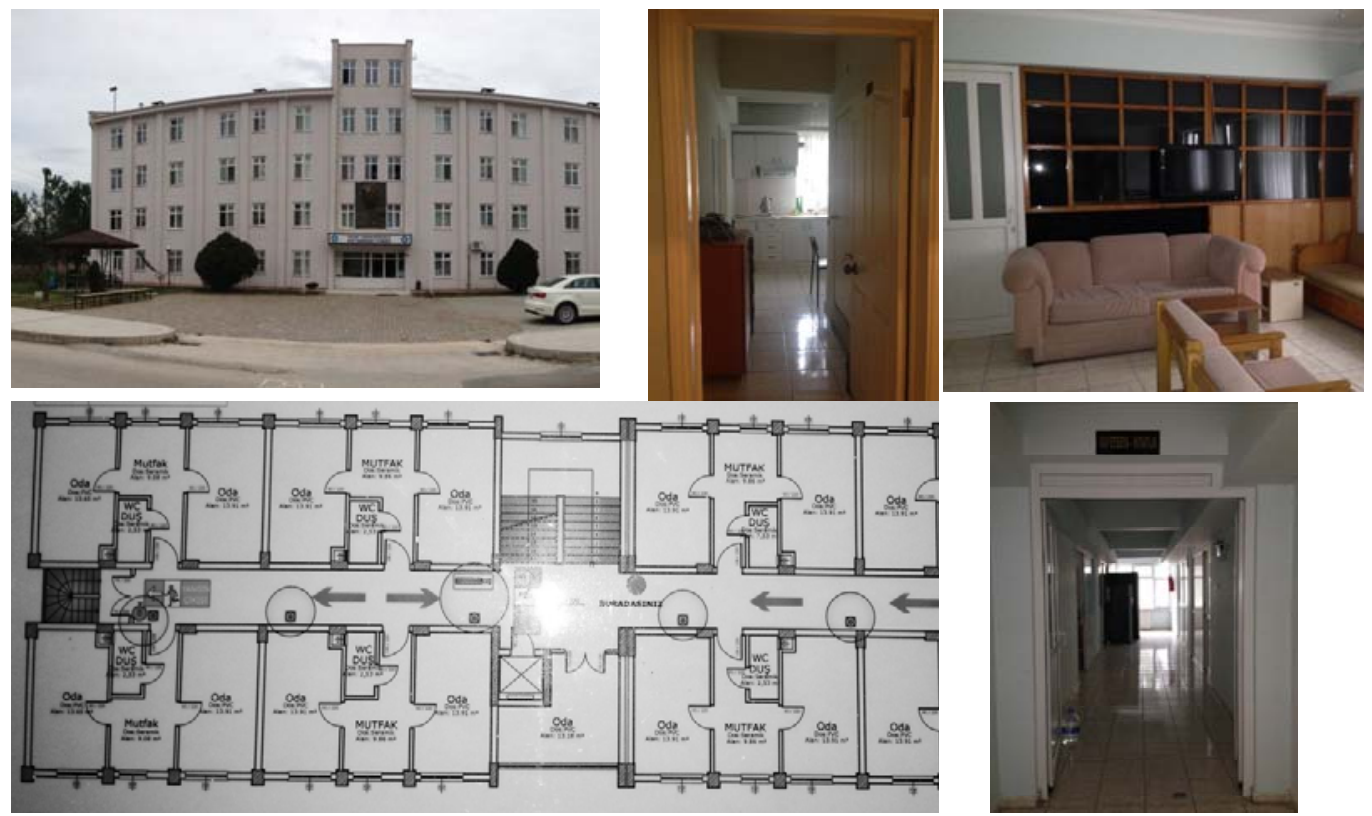

Figure 2. Guler Osman Koseoglu Female Dormitory

Nilufer Hatun Student Dormitory is five storeys. The building has a study hall, TV and recreation room, computer hall, laundry washing rooms, and laundry drying rooms. Similar to other dormitories there are no cafeterias or mess halls but there are vending machines for water, coffee, etc., and various convenience foods. The rooms accommodate 2 people and have bathrooms but do not have kitchens. There is an elevator, a main staircase and two fire escapes in the building. 

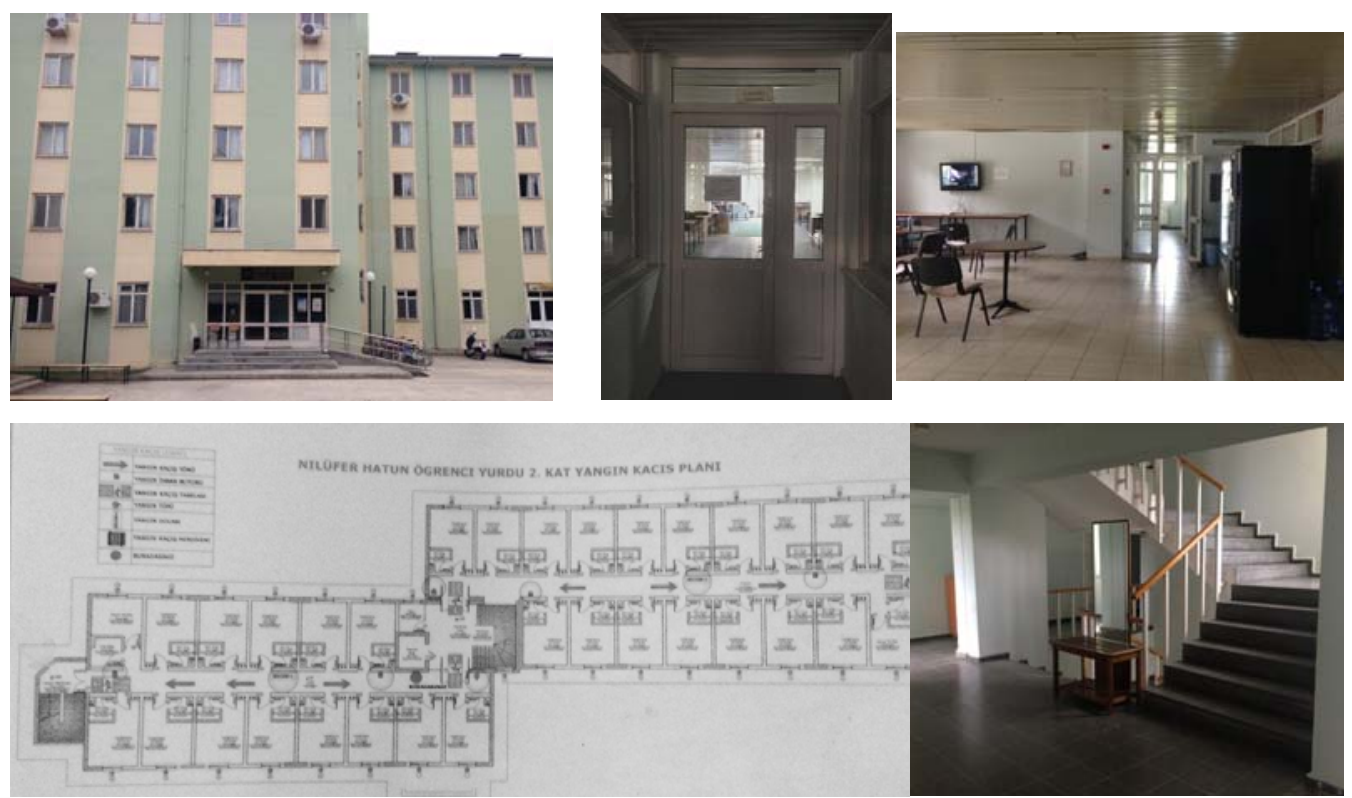

Figure 3. Nilufer Hatun Student Dormitory

Rabia Riza Bicen Student Dormitory is five storeys. The building has study halls, a TV and recreation room, computer hall, laundry washing rooms, and a laundry drying room. Similar to other dormitories there are no cafeterias or mess halls but there are vending machines for water, coffee, etc., and various convenience foods. It has two types of rooms; one that accommodate three people with a bathroom but no kitchen and another one that accommodate four people and has both a kitchen and bathroom. There is an elevator, a main staircase and three fire escapes in the building. 

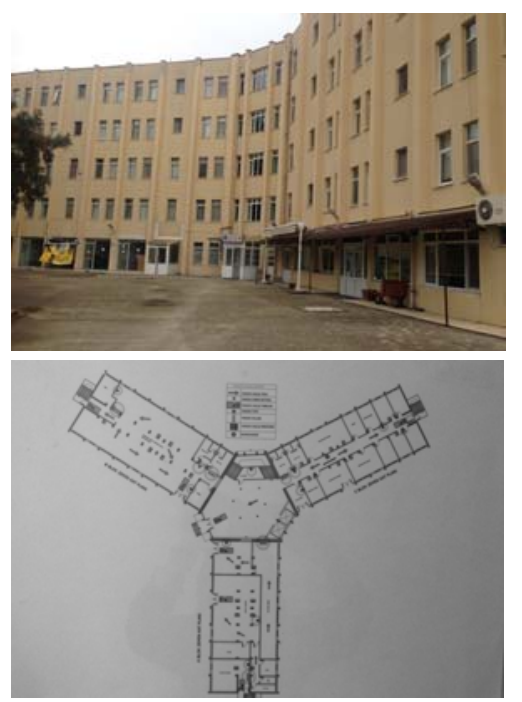

Figure 4. Rabia Rıza Bicen Student Dormitory
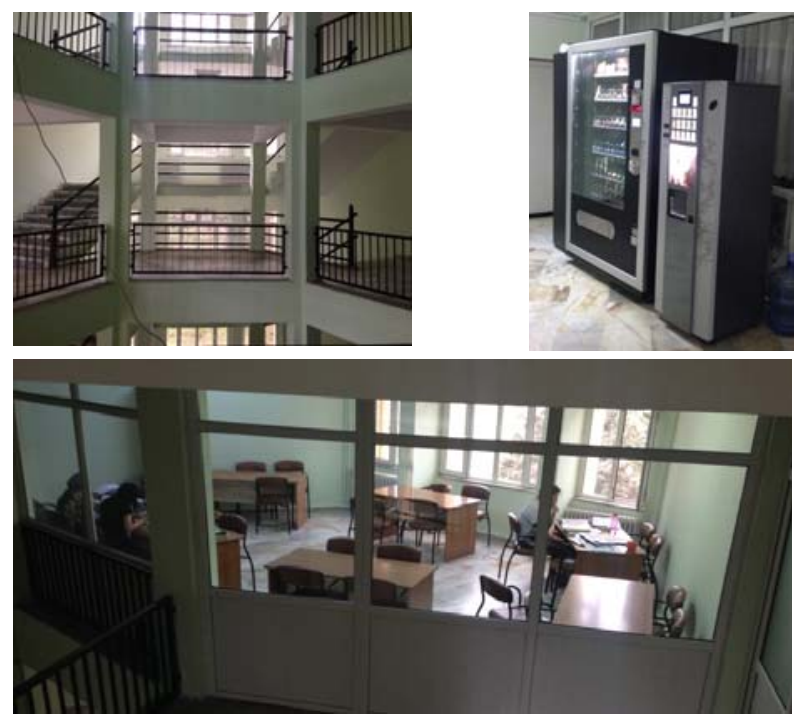

\section{Study Findings}

A "user satisfaction survey" was prepared to evaluate the indoor spatial usage experiences of the students in the scope of the study; the survey had 30 questions. To understand the level of satisfaction of students, the results of the survey were analysed. During the 2015-2016 education year 97 female students stayed at Guler Osman Köseoğlu Dormitory, 86 male students stayed at Nilufer Hatun Dormitory, and 107 female students stayed at Rabia Riza Bicen Dormitory. To make it easier to read and evaluate the graphics based on the number of people and percentages, 30 female students from Guler Osman Köseoğlu Dormitory, 30 male students from Nilufer Hatun Dormitory, and 40 female students from Rabia Riza Bicen Dormitory were selected for the survey (a total of 100 students), resulting in a survey participation rate of $34,5 \%$. Of the total participants, 30\% were males and $\% 70$ was females.

The youth period is defined by UNESCO as the ages between 15-25. According to the World Health Organization data the ages 10-19 is defined as adolescence, 15-24 as young, and the community ages 10-24 youth (Yaz1c1, 2001). According to the ages of the participants to the survey $72 \%$ are aged between $17-20,24 \%$ were aged between $21-24$, and $4 \%$ were aged between $25-28$.

In the scope of Design and Planning; 9 questions in total and 3 for each of the subheadings transportability, accessibility and ergonomics were asked; in the scope of "Physical Environmental Control" 12 questions in total and 3 for each of the subheadings thermal comfort, audio comfort, visual comfort, indoor air quality were asked; in the scope of Social Environment 3 questions were asked related to service areas. The questions were evaluated using a five point Likert scale.

In the scope of the survey under the Design - Planning heading, pedestrian transportability to dormitories, the perception of building entrance, the position of 
accommodation rooms in the building were evaluated as the "Transportability" criteria (Table 1).

Ease of access between storeys and obstacles, ease of access to toilets, bathrooms and other wet areas that are used frequently and ease of access between units are evaluated under "Accessibility" criteria (Table 2).

The size of the accommodation rooms of students in square meters, the ergonomics and size of the furniture, the width of the steps of the staircase and practicality of the risers were evaluated under the "Ergonomics" criteria (Table 3).

Table 1. User opinions related to transportability

\begin{tabular}{|c|c|c|c|c|c|c|c|}
\hline \multirow{2}{*}{\multicolumn{2}{|c|}{$\begin{array}{l}\text { Elements of Performance } \\
\text { ( transportability) }\end{array}$}} & \multicolumn{6}{|c|}{ Evaluation Terms } \\
\hline & & \multirow{2}{*}{$\begin{array}{l}\begin{array}{l}\text { very } \\
\text { satisfied }\end{array} \\
2\end{array}$} & \multirow{2}{*}{$\begin{array}{l}\text { satisfied } \\
7\end{array}$} & \multirow{2}{*}{$\begin{array}{l}\begin{array}{l}\text { neither } \\
\text { satisfied } \\
\text { nor } \\
\text { dissatisfied }\end{array} \\
5\end{array}$} & \multirow{2}{*}{$\begin{array}{l}\text { dissatisfied } \\
13\end{array}$} & \multirow{2}{*}{$\begin{array}{l}\text { very } \\
\text { dissatisfied } \\
3\end{array}$} & \multirow{2}{*}{$\begin{array}{l}\begin{array}{l}\text { can't } \\
\text { choose }\end{array} \\
0\end{array}$} \\
\hline \multirow{3}{*}{$\begin{array}{l}\text { pedestrian } \\
\text { transportability } \\
\text { to dormitories }\end{array}$} & $\begin{array}{l}\text { Guler } \\
\text { Osman }\end{array}$ & & & & & & \\
\hline & $\begin{array}{l}\text { Nilufer } \\
\text { Hatun }\end{array}$ & 3 & 8 & 3 & 15 & 1 & 0 \\
\hline & Rabia Rıza & 2 & 10 & 9 & 16 & 3 & 0 \\
\hline \multirow{3}{*}{$\begin{array}{l}\text { the perception } \\
\text { of building } \\
\text { entrance }\end{array}$} & $\begin{array}{l}\text { Guler } \\
\text { Osman }\end{array}$ & 4 & 14 & 4 & 7 & 1 & 0 \\
\hline & $\begin{array}{l}\text { Nilufer } \\
\text { Hatun }\end{array}$ & 6 & 12 & 5 & 6 & 1 & 0 \\
\hline & Rabia Riza & 6 & 15 & 7 & 9 & 3 & 0 \\
\hline \multirow{3}{*}{$\begin{array}{l}\text { the position of } \\
\text { accommodation } \\
\text { rooms }\end{array}$} & $\begin{array}{l}\text { Guler } \\
\text { Osman }\end{array}$ & 5 & 11 & 6 & 7 & 1 & 0 \\
\hline & $\begin{array}{l}\text { Nilufer } \\
\text { Hatun }\end{array}$ & 4 & 11 & 8 & 5 & 2 & 0 \\
\hline & Rabia Riza & 5 & 15 & 8 & 9 & 2 & 1 \\
\hline
\end{tabular}

Table 2. User opinions related to accessibility

\begin{tabular}{|c|c|c|c|c|c|c|c|}
\hline \multirow{2}{*}{\multicolumn{2}{|c|}{$\begin{array}{l}\text { Elements of Performance } \\
\text { (Accessibility) }\end{array}$}} & \multicolumn{6}{|c|}{ Evaluation Terms } \\
\hline & & \multirow{2}{*}{$\begin{array}{l}\begin{array}{l}\text { very } \\
\text { satisfied }\end{array} \\
0\end{array}$} & \multirow{2}{*}{$\begin{array}{l}\text { satisfied } \\
2\end{array}$} & \multirow{2}{*}{$\begin{array}{l}\text { neither } \\
\text { satisfied } \\
\text { nor } \\
\text { dissatisfied } \\
15\end{array}$} & \multirow{2}{*}{$\begin{array}{l}\text { dissatisfied } \\
9\end{array}$} & \multirow{2}{*}{$\begin{array}{l}\begin{array}{l}\text { very } \\
\text { dissatisfied }\end{array} \\
4\end{array}$} & \multirow{2}{*}{$\begin{array}{l}\begin{array}{l}\text { can't } \\
\text { choose }\end{array} \\
0\end{array}$} \\
\hline \multirow{3}{*}{$\begin{array}{l}\text { access } \\
\text { between } \\
\text { storey's and } \\
\text { obstacles }\end{array}$} & $\begin{array}{l}\text { Guler } \\
\text { Osman }\end{array}$ & & & & & & \\
\hline & $\begin{array}{l}\text { Nilufer } \\
\text { Hatun }\end{array}$ & 1 & 2 & 12 & 10 & 5 & 0 \\
\hline & Rabia Rıza & 0 & 5 & 14 & 13 & 6 & 2 \\
\hline \multirow{3}{*}{$\begin{array}{l}\text { access to } \\
\text { toilets, } \\
\text { bathrooms } \\
\text { wet areas }\end{array}$} & $\begin{array}{l}\text { Guler } \\
\text { Osman }\end{array}$ & 5 & 8 & 10 & 5 & 2 & 0 \\
\hline & $\begin{array}{l}\text { Nilufer } \\
\text { Hatun }\end{array}$ & 3 & 13 & 7 & 5 & 2 & 0 \\
\hline & Rabia Riza & 6 & 15 & 7 & 9 & 3 & 0 \\
\hline \multirow{3}{*}{$\begin{array}{l}\text { access } \\
\text { between } \\
\text { units }\end{array}$} & $\begin{array}{l}\text { Guler } \\
\text { Osman }\end{array}$ & 4 & 10 & 9 & 6 & 1 & 0 \\
\hline & $\begin{array}{l}\text { Nilufer } \\
\text { Hatun }\end{array}$ & 5 & 7 & 11 & 4 & 3 & 0 \\
\hline & Rabia Rıza & 4 & 13 & 13 & 7 & 3 & 0 \\
\hline
\end{tabular}


Table 3. User opinions related to ergonomics

\begin{tabular}{|c|c|c|c|c|c|c|c|}
\hline \multirow[b]{2}{*}{$\begin{array}{l}\text { Elements of } \\
\text { (Ergonomics) }\end{array}$} & \multirow[b]{2}{*}{ Performance } & \multicolumn{6}{|c|}{ Evaluation Terms } \\
\hline & & $\begin{array}{l}\text { very } \\
\text { satisfied }\end{array}$ & satisfied & $\begin{array}{l}\text { neither } \\
\text { satisfied } \\
\text { nor } \\
\text { dissatisfied }\end{array}$ & dissatisfied & $\begin{array}{l}\text { very } \\
\text { dissatisfied }\end{array}$ & $\begin{array}{l}\text { can't } \\
\text { choose }\end{array}$ \\
\hline \multirow{3}{*}{$\begin{array}{l}\text { square } \\
\text { meters }\end{array}$} & Guler Osman & 0 & 2 & 7 & 15 & 6 & 0 \\
\hline & Nilufer Hatun & 1 & 2 & 5 & 12 & 10 & 0 \\
\hline & Rabia Rıza & 0 & 4 & 11 & 17 & 8 & 0 \\
\hline \multirow{3}{*}{ furniture } & Guler Osman & 3 & 7 & 11 & 5 & 2 & 0 \\
\hline & Nilufer Hatun & 4 & 11 & 7 & 6 & 2 & 0 \\
\hline & Rabia Rıza & 4 & 12 & 14 & 7 & 3 & 0 \\
\hline \multirow{3}{*}{ staircase } & Guler Osman & 3 & 11 & 7 & 5 & 3 & 1 \\
\hline & Nilufer Hatun & 3 & 10 & 10 & 4 & 3 & 0 \\
\hline & Rabia Riza & 4 & 13 & 12 & 9 & 2 & 0 \\
\hline
\end{tabular}

In the second phase and in terms of physical environmental control the views of the users regarding indoor temperature and whether if there is a need for air conditioning during summers and winters were taken (Table 4). Thermal comfort is defined by The American Society of Heating, Refrigerating and Air-conditioning Engineers (ASHRAE) Standard 55 as satisfaction from the thermal conditions. Optimum thermal environments are defined as environments in which $80 \%$ or more of their users agree that the environment is acceptable. The factors that influence thermal environment are defined as heat, ventilation, humidity, thermal spread and filtered air quality.

Regarding "Audio Comfort", volume and building acoustics, noise of building installations and noise generated outside were evaluated (Figure 5).

Visual comfort quality is defined as the quality and quantity of the light source and how it brightens its close surroundings. The impact of colours in an environment and light sources, which are positioned at wrong angles, creates glares that negatively effects vision and as a result creates inadequate lighting levels. However adequate window sizes and positions enable adequate lighting throughout the day and removes glares.

Table 4. User opinions related to thermal comfort

\begin{tabular}{|c|c|c|c|c|c|c|c|}
\hline \multirow{2}{*}{\multicolumn{2}{|c|}{$\begin{array}{l}\text { Elements of Performance } \\
\text { (Thermal Comfort) }\end{array}$}} & \multicolumn{6}{|c|}{ Evaluation Terms } \\
\hline & & $\begin{array}{l}\text { very } \\
\text { satisfied }\end{array}$ & satisfied & $\begin{array}{l}\text { neither } \\
\text { satisfied } \\
\text { nor } \\
\text { dissatisfied }\end{array}$ & dissatisfied & $\begin{array}{l}\text { very } \\
\text { dissatisfied }\end{array}$ & $\begin{array}{l}\text { can't } \\
\text { choose }\end{array}$ \\
\hline \multirow{3}{*}{$\begin{array}{l}\text { indoor } \\
\text { temperature } \\
\text { in summer }\end{array}$} & Guler Osman & 1 & 7 & 14 & 5 & 1 & 2 \\
\hline & $\begin{array}{l}\text { Nilufer } \\
\text { Hatun }\end{array}$ & 2 & 7 & 15 & 4 & 1 & 1 \\
\hline & Rabia Riza & 0 & 11 & 21 & 6 & 1 & 1 \\
\hline \multirow{3}{*}{$\begin{array}{l}\text { indoor } \\
\text { temperature } \\
\text { in winter }\end{array}$} & Guler Osman & 2 & 12 & 9 & 6 & 1 & 0 \\
\hline & $\begin{array}{l}\text { Nilufer } \\
\text { Hatun }\end{array}$ & 3 & 10 & 9 & 6 & 2 & 0 \\
\hline & Rabia Riza & 1 & 21 & 9 & 8 & 1 & 0 \\
\hline \multirow{3}{*}{$\begin{array}{l}\text { air } \\
\text { conditioning } \\
\text { use }\end{array}$} & Guler Osman & 1 & 12 & 5 & 2 & 1 & 9 \\
\hline & $\begin{array}{l}\text { Nilufer } \\
\text { Hatun }\end{array}$ & 1 & 10 & 11 & 2 & 0 & 6 \\
\hline & Rabia Rıza & 1 & 14 & 21 & 1 & 0 & 3 \\
\hline
\end{tabular}


Table 5. User opinions related to audio comfort

\begin{tabular}{|c|c|c|c|c|c|c|c|}
\hline \multirow[b]{2}{*}{$\begin{array}{l}\text { Elements of } \\
\text { (Audio Comf }\end{array}$} & \multirow[b]{2}{*}{$\begin{array}{l}\text { Performance } \\
\text { prt) }\end{array}$} & \multicolumn{6}{|c|}{ Evaluation Terms } \\
\hline & & $\begin{array}{l}\text { very } \\
\text { satisfied }\end{array}$ & satisfied & $\begin{array}{l}\text { neither } \\
\text { satisfied } \\
\text { nor } \\
\text { dissatisfied }\end{array}$ & dissatisfied & $\begin{array}{l}\text { very } \\
\text { dissatisfied }\end{array}$ & $\begin{array}{l}\text { can't } \\
\text { choose }\end{array}$ \\
\hline \multirow{3}{*}{$\begin{array}{l}\text { indoor } \\
\text { acoustical } \\
\text { comfort }\end{array}$} & $\begin{array}{l}\text { Guler } \\
\text { Osman }\end{array}$ & 0 & 3 & 9 & 14 & 4 & 0 \\
\hline & $\begin{array}{l}\text { Nilufer } \\
\text { Hatun }\end{array}$ & 0 & 1 & 8 & 15 & 6 & 0 \\
\hline & Rabia Rıza & 0 & 3 & 14 & 15 & 6 & 2 \\
\hline \multirow{3}{*}{$\begin{array}{l}\text { outdoor } \\
\text { noisy }\end{array}$} & $\begin{array}{l}\text { Guler } \\
\text { Osman }\end{array}$ & 0 & 2 & 15 & 12 & 4 & 0 \\
\hline & $\begin{array}{l}\text { Nilufer } \\
\text { Hatun }\end{array}$ & 0 & 1 & 12 & 10 & 5 & 0 \\
\hline & Rabia Riza & 0 & 2 & 17 & 11 & 8 & 2 \\
\hline \multirow{3}{*}{$\begin{array}{l}\text { plumbing } \\
\text { noise }\end{array}$} & $\begin{array}{l}\text { Guler } \\
\text { Osman }\end{array}$ & 8 & 12 & 6 & 3 & 1 & 0 \\
\hline & $\begin{array}{l}\text { Nilufer } \\
\text { Hatun }\end{array}$ & 11 & 12 & 4 & 2 & 0 & 1 \\
\hline & Rabia Rıza & 12 & 16 & 7 & 2 & 0 & 3 \\
\hline
\end{tabular}

Table 6. User opinions related to visual comfort

\begin{tabular}{llllllll}
\hline \multirow{2}{*}{$\begin{array}{l}\text { Elements of Performance } \\
\text { (Visual Comfort) }\end{array}$} & $\begin{array}{l}\text { Evaluation Terms } \\
\text { very } \\
\text { satisfied }\end{array}$ & satisfied & $\begin{array}{l}\text { neither } \\
\text { satisfied } \\
\text { nor } \\
\text { dissatisfied }\end{array}$ & dissatisfied & $\begin{array}{l}\text { very } \\
\text { dissatisfied }\end{array}$ & $\begin{array}{l}\text { can't } \\
\text { choose }\end{array}$ \\
\hline \multirow{2}{*}{$\begin{array}{l}\text { natural } \\
\text { lighting }\end{array}$} & Guler Osman & 2 & 7 & 5 & 13 & 3 & 0 \\
\hline \multirow{2}{*}{ lighting } & Nilufer Hatun & 3 & 8 & 3 & 15 & 1 & 0 \\
& Rabia Riza & 2 & 10 & 9 & 16 & 3 & 0 \\
\hline \multirow{2}{*}{$\begin{array}{l}\text { color } \\
\text { selection }\end{array}$} & Guler Osman & 7 & 10 & 8 & 3 & 2 & 0 \\
& Nilufer Hatun & 4 & 12 & 8 & 2 & 3 & 1 \\
\hline & Rabia Riza & 9 & 16 & 8 & 2 & 4 & 1 \\
\hline & Guler Osman & 8 & 9 & 7 & 4 & 1 & 1 \\
& Nilufer Hatun & 7 & 13 & 6 & 2 & 1 & 1 \\
\hline
\end{tabular}

For the "Visual Comfort" criteria, the building was evaluated if natural illumination was sufficient, if the condition of artificial illumination and the wall coatings and colour were suitable to concentrate (Table 6).

Related to "Indoor Air Quality", condition of natural ventilation, satisfaction from indoor air quality, odour problems in rooms, wet areas and common areas were taken into consideration (Figure 7). Indoor air quality is defined by ASHRAE (1989) Standard 62 as indoor air that does not contain pollutants and that does not dissatisfy $80 \%$ or more of the users (CEN 1998). 
Table 7. User opinions for indoor air quality

\begin{tabular}{|c|c|c|c|c|c|c|c|}
\hline \multirow{2}{*}{\multicolumn{2}{|c|}{$\begin{array}{l}\text { Elements of Performance } \\
\text { (Indoor Air Quality) }\end{array}$}} & \multicolumn{6}{|c|}{ Evaluation Terms } \\
\hline & & $\begin{array}{l}\text { very } \\
\text { satisfied }\end{array}$ & satisfied & $\begin{array}{l}\text { neither } \\
\text { satisfied } \\
\text { nor }\end{array}$ & dissatisfied & $\begin{array}{l}\text { very } \\
\text { dissatisfied }\end{array}$ & $\begin{array}{l}\text { can't } \\
\text { choose }\end{array}$ \\
\hline \multirow{3}{*}{$\begin{array}{l}\text { odor in } \\
\text { rooms }\end{array}$} & Guler Osman & 3 & 9 & 10 & 6 & 2 & 0 \\
\hline & Nilufer Hatun & 5 & 7 & 7 & 8 & 3 & 0 \\
\hline & Rabia Riza & 4 & 9 & 14 & 11 & 2 & 0 \\
\hline \multirow{3}{*}{$\begin{array}{l}\text { odor in } \\
\text { wetsuits }\end{array}$} & Guler Osman & 3 & 8 & 12 & 4 & 3 & 0 \\
\hline & Nilufer Hatun & 3 & 7 & 3 & 13 & 4 & 0 \\
\hline & Rabia Riza & 2 & 11 & 9 & 15 & 3 & 0 \\
\hline \multirow{3}{*}{$\begin{array}{l}\text { odor in } \\
\text { common } \\
\text { areas }\end{array}$} & Guler Osman & 1 & 7 & 14 & 5 & 1 & 2 \\
\hline & Nilufer Hatun & 2 & 7 & 15 & 4 & 1 & 1 \\
\hline & Rabia Riza & 0 & 16 & 14 & 7 & 3 & 0 \\
\hline
\end{tabular}

In the third phase, the condition of indoor spaces for common usage, sufficient spaces for catering, open and green spaces for socializing were evaluated under the "Service Areas" heading (Table 8).

Table 8. User opinions for service areas

\begin{tabular}{|c|c|c|c|c|c|c|c|}
\hline \multirow{2}{*}{\multicolumn{2}{|c|}{$\begin{array}{l}\text { Elements of Performance } \\
\text { ( Service Areas ) }\end{array}$}} & \multicolumn{6}{|c|}{ Evaluation Terms } \\
\hline & & $\begin{array}{l}\text { very } \\
\text { satisfied }\end{array}$ & satisfied & $\begin{array}{l}\text { neither } \\
\text { satisfied } \\
\text { nor }\end{array}$ & dissatisfied & $\begin{array}{l}\text { very } \\
\text { dissatisfied }\end{array}$ & $\begin{array}{l}\text { can't } \\
\text { choose }\end{array}$ \\
\hline \multirow{3}{*}{$\begin{array}{l}\text { indoor } \\
\text { spaces for } \\
\text { common } \\
\text { usage }\end{array}$} & Guler Osman & 1 & 3 & 10 & 9 & 7 & 0 \\
\hline & Nilufer Hatun & 2 & 8 & 12 & 12 & 6 & 0 \\
\hline & Rabia Rıza & 5 & 17 & 8 & 6 & 3 & 1 \\
\hline \multirow{3}{*}{$\begin{array}{l}\text { spaces for } \\
\text { catering }\end{array}$} & Guler Osman & 6 & 9 & 8 & 5 & 2 & 0 \\
\hline & Nilufer Hatun & 5 & 11 & 6 & 4 & 4 & 0 \\
\hline & Rabia Riza & 6 & 12 & 11 & 8 & 3 & 0 \\
\hline \multirow{3}{*}{$\begin{array}{l}\text { open and } \\
\text { green } \\
\text { spaces }\end{array}$} & Guler Osman & 3 & 9 & 9 & 7 & 2 & 0 \\
\hline & Nilufer Hatun & 2 & 11 & 8 & 4 & 4 & 1 \\
\hline & Rabia Riza & 6 & 13 & 9 & 8 & 4 & 0 \\
\hline
\end{tabular}

\section{Evaluation and Conclusion}

In the scope of the study for creating design criteria for new dormitories, it was important to define issues that students living in dormitories felt dissatisfied. In this regard the results of the study are summarized in the table below (Table 9). 
Table 9. Evaluation results of building usage of students

\begin{tabular}{|c|c|c|c|c|c|c|c|}
\hline \multirow{2}{*}{\multicolumn{2}{|c|}{ Elements of Performance }} & \multicolumn{2}{|c|}{ Guler Osman } & \multicolumn{2}{|c|}{ Nilufer Hatun } & \multicolumn{2}{|c|}{ Rabia Bicen } \\
\hline & & $\mathrm{S}$ & $\mathbf{D}$ & $\mathbf{S}$ & $\mathbf{D}$ & $\mathbf{S}$ & $\mathbf{D}$ \\
\hline \multirow{3}{*}{ transportability } & transportability & to & -8 & & -3 & & -8 \\
\hline & the perception of building entrance & 13 & & 16 & & 12 & \\
\hline & the position of accommodation rooms & 12 & & 10 & & 12 & \\
\hline \multirow{3}{*}{ accessibility } & access between storey's and obstacles & & -15 & & -16 & & -20 \\
\hline & access to toilets, bathrooms, wet areas & 9 & & 10 & & 12 & \\
\hline & access between units & 10 & & 7 & & 8 & \\
\hline \multirow{3}{*}{ ergonomics } & The size of the rooms in square meters & & -25 & & -28 & & -29 \\
\hline & ergonomics and size of the furniture & 4 & & 9 & & 7 & \\
\hline & width of the steps of the staircase & 6 & & 6 & & 8 & \\
\hline \multirow{3}{*}{$\begin{array}{l}\text { thermal } \\
\text { comfort }\end{array}$} & indoor temperature in summer & 2 & & 5 & & 3 & \\
\hline & indoor temperature in winter & 8 & & 6 & & 13 & \\
\hline & air conditioning use & 10 & & 10 & & 15 & \\
\hline \multirow{3}{*}{ audio comfort } & indoor acoustical comfort & & -19 & & -26 & & -24 \\
\hline & noisy outdoor & & -18 & & -19 & & -25 \\
\hline & plumbing noise & 23 & & 32 & & 38 & \\
\hline \multirow{3}{*}{ visual comfort } & natural lighting & & -8 & & -3 & & -8 \\
\hline & lighting & 17 & & 12 & & 24 & \\
\hline & color selection & 19 & & 23 & & 31 & \\
\hline \multirow{3}{*}{$\begin{array}{l}\text { indoor } \\
\text { quality }\end{array}$} & Odor in rooms & 5 & & 3 & & 2 & \\
\hline & odor in wetsuits & 4 & & & -8 & & -6 \\
\hline & odor in common areas & 2 & & 5 & & 3 & \\
\hline \multirow{3}{*}{ service areas } & indoor spaces for common usage & & -18 & & -12 & 15 & \\
\hline & spaces for catering & 12 & & 9 & & 10 & \\
\hline & open and green spaces & 4 & & 3 & & 9 & \\
\hline
\end{tabular}

very satisfied 2, satisfied 1, neither satisfied nor dissatisfied 0, dissatisfied-1,very dissatisfied -2, can't choose 0

In general, according to the answers provides by the participants in the area examined:

From the Transportability and Accessibility point of view: the dissatisfaction related to pedestrian access and handicapped access is likely to be derived from the long distance of the dormitories from the campus, and because handicapped users were not taken into account during the design stages of the buildings.

From the Ergonomics point of view; discontent from the size (in square meters) were expressed.

Thermal comfort; was achieved sufficiently in every season. According to the surveys and interviews, rooms and common areas were adequately cooled in summers and heated in winters. According to the answers provided by the participants it was understood that there were no additional needs for air conditioning systems.

Audio comfort; is not achieved sufficiently. The number of students that believe audio comfort is not achieved in rooms and common areas is high. It was also seen that the 
noise entering the building from outside is creating discomfort. The reason behind this is the location of the dormitories, which is a crowded area of the campus.

When evaluated from the viewpoint of visual comfort; it was seen that natural illumination was not deemed adequate. The reason for this is the small size of the windows.

When the indoor air quality is evaluated; it has been seen that the odour in wet areas is creating dissatisfaction.

When the service areas are evaluated; it has been seen that the common areas are not adequate and the spaces that could provide social interaction are not used efficiently, which reduces satisfaction.

For new dormitory buildings to be designed, the issues that create dissatisfaction in the current buildings should be improved to increase the usage of such buildings by students. Better designed dormitories will increase their social and education adoption by the students. Better designed comfort conditions will increase the motivation of students and also their social status and achievement exponentially.

\section{References}

ASHRAE Standard 62 (1989). ASHRAE handbook - Ventilation for acceptable indoor air quality

ASHRAE Standard 55 (1993). ASHRAE handbook - Fundamentals, chapter 8, Physigological principles and thermal comfort

ASHRAE. (2003). Thermal environment conditions for human occupancy. ASHRAE Standard 55-1992.

Cella, D. F. (1996). Quality of life: concepts and definition. J Pain Symptom Manage; 9:186-92.

CEN. (1998). Ventilation for Buildings: Design criteria for the indoor environment. european committee for standardization. CR 1752.

Ersoy, A. F., Arpacı, F. (2003). Universite Öğrencilerinin Konut Kosullarının ve Konutta Yasamayı Tercih Etme Nedenlerinin İncelenmesi, Milli Ĕ̈itim Dergisi, 158.

Google Earth, 2016

Hassanain, M. A. (2007). Post-Occupancy Indoor Environmental Quality Evaluation of Student Housing Facilities, Architectural Engineering and Design Management, 3, 249-256. doi: http://dx.doi.org/10.1080/17452007.2007.9684646

Matheny, K. B., Curlette W. L., Aysan, F., Harrington, A. (2002). Coping resources, perceived stres and life satisfaction among Turkish and American university students. Int J Stress Management 9: 81-97.

Sahin, H. (1997). Eski bir kavram yeni bir olcut: Yasam kalitesi. Toplum ve Hekim;12: 40-6.

Yazıc1, E. (2001). Üniversite Gençliğinin Sosyo-Kültürel Profili Üzerine Bir Alan Araştırması: Gazi Üniversitesi Örneği, Ankara: G.Ü. İletişim Fakültesi Yayınları. 